\title{
Implikasi Politik Hukum Pengaturan Pertanggungjawaban Kinerja Kepala Daerah Pasca Reformasi
}

\author{
Alan Bayu Aji \\ alanbayuaji@gmail.com
}

\begin{abstract}
This study aims to determine the objective conditions regarding the legal politics of managing the performance accountability of regional heads after the reform. The formulations of the problem include, first, how is the legal politics of the regulation for performance accountability of regional heads after the reform, and second, what is the ideal model of regional head accountability to the regional representative council (DPRD). This research is normative juridical research in which the data used is secondary data in the form of legal materials. In addition, this study uses theories as an analysis tool. The results show that the legal politics of regional head accountability has shifted from DPRD to the central government. The shift is caused by an empirical practice during the enactment of Law No. 22 of 1999 and the domination of DPRD, but the accountability is then shifted to the central government. Domination is also shown by the central government in supervising regional governments, thus minimizing the role of DPRD as a regional representative body with supervisory function. The performance accountability of regional head should be initially presented to DPRD to create equal partnership relations between the two institutions and to place DPRD outside the regional administration element, enabling DPRD to carry out the supervisory function optimally towards directly elected regional heads.
\end{abstract}

Keywords: Legal politics; accountability; regional heads

\begin{abstract}
Abstrak
Penelitian ini bertujuan untuk mengetahui kondisi obyektif mengenai politik hukum pengaturan pertanggungjawaban kinerja kepala daerah pasca reformasi. Adapun rumusan masalah dalam penelitian ini adalah: pertama, bagaimana politik hukum pengaturan pertanggungjawaban kinerja kepala daerah pasca reformasi, dan kedua, bagaimana model ideal pertanggungjawaban Kepala Daerah kepada DPRD. Penelitian ini merupakan penelitian yuridis normatif di mana data yang digunakan adalah data sekunder berupa bahan hokum. Hasil penelitian ini menyimpulkan bahwa politik hukum pertanggungjawaban kepala daerah mengalami pergeseran yang semula kepada DPRD beralih kepada Presiden. Pergerseran tersebut diakibatkan praktik empiris yang terjadi pada periode berlakunya UU No. 22 Tahun 1999 dan dominasi DPRD. Namun ketika pertanggungjawaban itu beralih kepada pemerintah pusat dominasi juga diperlihatkan oleh pemerintah pusat terhadap pengawasan penyelenggaraan pemerintahan daerah, sehingga membuat minimnya peran DPRD sebagai lembaga perwakilan rakyat daerah yang memiliki fungsi pengawasan. Terkait pertanggungjawaban kinerja kepala daerah seharusnya dipertanggungjawabkan kepada DPRD terlebih dahulu untuk menciptakan hubungan kemitraan sejajar antar kedua lembaga dan menempatkan DPRD di luar unsur penyelenggara pemerintahan daerah, agar DPRD dapat menjalankan fungsi pengawasan secara optimal terhadap Kepala Daerah yang dipilih secara langsung.
\end{abstract}

Kata-kata Kunci : Politik hukum; pertanggungjawaban; kepala daerah 


\section{Lxx Renaissance No. 2 VOL. 2 JULI 2017: 231 - 258}

\section{Pendahuluan}

Pasca reformasi di Indoensia, telah terjadi sebuah bentuk perubahan sistem pemerintahan yang semula otoriter menjadi pemerintahan yang lebih demokratis. Bentuk pemerintahan yang demokratis tersebut salah satunya adalah dibukanya pintu masuk masyarakat dalam penyelenggaraan pemerintahan. Selain peran serta masyarakat yang dibangun, ada juga sebuah kesepakatan penyelenggaraan pemerintahan daerah yang demokratis, di mana pemerintahan yang demokratis tersebut nampak ketika ditetapkannya UU No. 22 Tahun 1999 tentang Pemerintahan Daerah. Undang-undang tersebut memberikan paradigma baru dalam pelaksanaan otonomi daerah dalam negara kesatuan. Otonomi daerah ditempatkan dalam lingkup yang nyata dan seluas-luasnya, sehingga pemerintahan daerah ketika itu begitu leluasa dalam menjalankan manajemen pemerintahan. Hal yang krusial saat itu salah satunya adalah pemilihan kepala daerah secara demokratis oleh DPRD, di mana sebelumnya pengisian jabatan kepala daerah menjadi kewenangan pemerintah pusat.

Pemilihan kepala daerah secara demokratis yang dilakukan oleh DPRD memberikan dampak yang cukup mendasar yaitu terkait pertanggungjawaban kinerja Kepala Daerah. Pertanggungjawaban tersebut beralih yang semula kepada pemerintah pusat atau presiden secara hierarkis, namun ketika itu beralih kepada DPRD secara mutlak. ${ }^{1}$ Selain pemilihan kepala daerah, DPRD juga memiliki hak untuk menerima Laporan Pertanggungjawaban Kepala Daerah yang kemudian di singkat LPJ Kepala Daerah. ${ }^{2}$ Terkait dengan LPJ Kepala Daerah ada satu hal yang menarik bahwa DPRD dapat menolak LPJ tersebut dan akan berujung pada pemberhentian kepala daerah. Sebagai contoh telah terjadi dalam beberapa kasus yaitu hubungan disharmonisasi antara Wali Kota Surabaya Bambang DH dengan DPRD. LPJ Walikota Bambang DH ditolak pada 12 Juni 2002. Saat itu ada tiga fraksi di DPRD Surabaya yaitu FKB, F.Gabungan, dan F.TNI/Polri menolak LPJ Tahunan Walikota Bambang DH. Kasus penolakan LPJ ini didasarkan karena Bambang DH memiliki argumen bahwa LPJ yang diterima DPRD Surabaya itu menjadi

\footnotetext{
${ }^{1}$ Lihat Pasal 31 ayat (2) dan Pasal 32 ayat (2) Undang-Undang Nomor 22 Tahun 1999

${ }^{2}$ Lihat ketentuan Pasal dalam Peraturan Pemerintah Nomor 108 Tahun 2000
} 
tanggungjawab Walikota sebelumnya yaitu Wali Kota Sunarto Sumoprawiro "Cak Narto" yang dipecat oleh DPRD karena alasan kesehatan. Sehingga Bambangs DH menolak untuk merevisinya. ${ }^{3}$

Seiring berjalannya waktu ada anggapan berlakunya UU No. 22 Tahun 1999 lebih mencerminkan pemerintahan parlementer, padahal diketahui pasca amendemen UUD NRI 1945 bentuk negara Indonesia adalah Negara Kesatuan dengan sistem presidensial. Sehingga perlu ada penyesuaian dan evaluasi terhadap UU No. 22 Tahun 1999 di mana dalam prakteknya lebih mencerminkan dominasi DPRD. Sebelum dilakukan evaluasi secara menyeluruh terhadap UU No. 22 Tahun 1999, terlebih dahulu telah diubah beberapa kewenangan DPRD yang salah satunya terkait dengan hak meminta LPJ Kepala Daerah menjadi LKPJ Kepala Daerah. Perubahan dari LPJ ke LKPJ sudah dimulai ketika ditetapkan UU No. 22 Tahun 2003 tentang Susunan dan Kedudukan MPR, DPR, DPD, dan DPRD. Perubahan dari LPJ menjadi LKPJ memberikan konsekuensi bahwa DPRD sudah tidak lagi memiliki kewenangan untuk meberhentikan Kepala Daerah dengan alasan LKPJnya ditolak. ${ }^{4}$ Terkait dengan LKPJ semakin dipetegas dalam UU No. 32 Tahun 2004 tentang Pemerintahan Daerah sebagai pengganti UU No. 22 Tahun 1999. Kepala Daerah ketika itu sudah tidak lagi dipilih secara langsung oleh DPRD sehingga tidak bertanggungjawab secara mutlak kepada DPRD.

Pertanggungjawaban Kepala Daerah saat ini terbagi dalam beberapa cara yaitu pertanggungjawaban Kepala Daerah kepada pemerintah pusat melalui Laporan Penyelenggaraan Pemerintah Daerah (LPPD). Pertanggungjawaban Kepala Daerah kepada DPRD melalui LKPJ sebagaimana dijelaskan sebelumnya, dan pertanggungjawaban kepala daerah secara langsung kepada masyarakat melalui Informasi Laporan Penyelenggaraan Pemerintahan Daerah (ILPPD). Cukup menarik untuk dikaji secara mendalam terkait pertanggungjawaban Kepala Daerah pasca reformasi, karena telah terjadi perubahan yang semula kepada DPRD

3 Tri Ratnawati, Problematik. Implementasi UU No. 22 Tabun 1999, dalam Membangun Format Baru Otonomi Daerah, LIPI Press, Jakarta, 2006, hlm. 137.

${ }^{4}$ Daftar Inventaris Masalah dalam pembahasan RUU tentang MPR, DPR, DPD, dan DPRD pada 2003 yang kemudian disahkan menjadi UU No. 22 Tahun 2003. 
sekarang beralih kepada pemerintah pusat, DPRD, dan masyarakat. Namun harus diperhatikan saat ini pertanggungjawaban Kepala Daerah begitu didominasi oleh pemerintah pusat. Dominasi tersebut didasarkan bahwa kewenangan atau urusan pemerintahan daerah itu datang dari pemerintah pusat sebagai bentuk hubungan desentralisasi dalam negara kesatuan. Berangkat dari penjelasan di atas penulis merasa tertarik untuk mengkajinya dan ingin melihat bagaimana pertanggungjawaban saat ini bila disandingkan dengan DPRD yang memiliki fungsi pengawasan dan sebagai representasi masyarakat.

\section{Rumusan Masalah}

Berangkat dari latar belakang yang telah dikemukakan di atas maka peneliti menyimpulkan adanya rumusan masalah sebagai berikut: pertama, bagaimana politik hukum pengaturan pertanggungjawaban kepala daerah pasca reformasi? Kedua, bagaimana model yang ideal pertanggungjawaban Kepala Daerah kepada Dewan Perwakilan Rakyat Daerah?

\section{Tujuan Penelitian}

Penelitian yang baik adalah penelitian yang mempunyai tujuan dan maksud yang jelas, adapun tujuan dari penelitian ini adalah pertama, mengetahui politik hukum pengaturan pertanggungjawaban kepala daerah pasca reformasi. Kedua, mengetahui model ideal pertanggungjawaban Kepala Daerah kepada Dewan Perwakilan Rakyat Daerah sebagai representasi masyarakat.

\section{Metode Penelitian}

Penelitian ini lebih menitik beratkan pada penelitian yuridis normatif dengan melihat dan mempelajari, dan memahami bahan hukum sebagai data, terutama bahan hukum yang berkaitan dengan pertanggungjawaban kepala daerah. Selain bahan hukum, penelitian ini juga akan menyajikan teori teori tentang otonomi daerah dan pertanggungjawbaan penyelenggaraan pemerintahan daerah, yang kemudian dari kajian bahan hukum dan teoritis tersebut akan dijabarkan hal-hal yang terkait pertanggungjawaban kinerja kepala daerah pasca reformasi. 


\section{Hasil Penelitian dan Pembahasan}

\section{Politik Hukum Pemerintahan Daerah}

Salah satu aspek konstitusional penyelenggaraan negara dan pemerintahan sejak Indonesia merdeka adalah persoalan berkaitan dengan penyelenggaraan otonomi sebagai subsistem negara kesatuan. Pemikiran mengenai otonomi sebagai alternatif dari pilihan bentuk negara federal telah diletakkan sejak masa pergerakan kemerdekaan. Pada saat menyusun UUD 1945, otonomi termasuk salah satu pokok yang dibicarakan dan kemudian dimuat dalam Undang-Undang Dasar. Demikian pula selanjutnya, dalam pengertian Undang-Undang Dasarseperti dalam UUDS 1950- otonomi tetap tercantum bahkan lebih dijelaskan. Pada masa Republik Indonesia Serikat, prinsip-prinsip otonomi tetap dijelaskan pada negara-negara bagian atau daerah bagian. Bahkan Undang-Undang pertama yang dibentuk masa Indonesia Merdeka yaitu Undang-Undang No. 1 Tahun 1945 mengatur mengenai otonomi. Berdasarkan kenyataan-kenyataan itu tidaklah berlebihan apabila otonomi dapat dipandang sebagai salah satu sendi penyelenggaraan negara dan pemerintahan dalam perumahan Indonesia Merdeka. ${ }^{5}$

Otonomi bukan sekedar pemencaran penyelenggaraan pemerintahan untuk mencapai efisiensi dan efektifitas pemerintahan. Otonomi adalah sebuah tatanan ketatanegaraan (staatsrechtelijk), bukan hanya tatanan administrasi negara (administratiefrechtelijk). Sebagai tatanan ketatanegaraan, otonomi berkaitan dengan dasar-dasar bernagara dan susunan organiasasi negara. Sistem pemerintahan otonomi yang diselenggarakan atas dasar permusyawaratan rakyat daerah yang bersangkutan melalui wakil-wakil mereka memungkinkan perluasan partisipasi demokrasi rakyat. Satuan-satuan pemerintahan otonomi yang mandiri dan demokratis juga akan lebih mendekatkan pemerintahan kepada rakyat sehingga berbagai kepentingan rakyat yang berbeda-beda dapat dilayani secara wajar. ${ }^{6}$

${ }^{5}$ Bagir Manan, Menyongsong Fajar Otonomi Daerah, Cetakan kedua, PSH FH UII, Yogyakarta, 2002, hlm. 21.

${ }^{6}$ Ibid., hlm. 25. 
Secara konseptual ada beberapa alasan otonomi daerah memberikan dampak positif bagi kesejahteraan daerah, menurut A. Sony Keraf berpendapat ada beberapa alasan, yaitu7:

1) Otonomi daerah mendekatkan pengambilan kebijakan dan keputusan publik dengan rakyat di daerah, akan lebih seusai dengan kondisi daerah.

2) Melalui otonomi daerah ada kontrol lebih langsung dan lebih cepat, bahkan lebih murah dari masyarakat dan berbagai kelompok kepentingan di daerah terhadap kebijakan pro rakyat.

3) Kepentingan nasyarakat lokal akan lebih diperhatikan dan diakomodasi.

4) Nasib daerah ditentukan oleh daerah itu sendiri, sehingga pemerintah daerah dan masyarakat setempat akan sangat serius dalam membangun daerahnya sendiri.

Secara konstitusiaonal otonomi daerah juga menjadi sebuah kesepakatan yang kemudian dijamin dalam UUD NRI 1945. Menurut Bagir Manan ada beberapa prinsip yang sejatinya ingin disampaikan, agar dalam pelaksanaan otonomi daerah dan penyelenggaraan pemerintahan daerah lebih terjamin. Hal-hal tersebut nampak pada prinsip-prinsip dan ketentuan-ketentuan berikut: ${ }^{8}$

a. Prinsip daerah mengatur dan mengurus sendiri urusan pemerintahan menurut asas otonomi dan tugas pembantuan (Pasal 18 ayat (2)). Ketentuan ini menegaskan bahwa pemerintahan daerah adalah suatu pemerintahan otonom dalam negara kesatuan Republik Indonesia. Dalam pemerintahan daerah hanya ada pemerintahan otonom (termasuk tugas pembantuan). Dengan perkataan lain, ketentuan ini hanya mengatur otonomi.

b. Prinsip menjalankan otonomi seluas-luasnya (Pasal 18 ayat (5)). Untuk menegaskan kesepakatan yang telah ada pada saat penyusunan UUD 1945 dan menghindari pengebirian otonomi menuju sentralisasi, maka sangat tepat, pasal 18 yang baru menegaskan pelaksanaan otonomi yang seluas-luasnya. Daerah berhak mengatur dan mengurus segala urusan atau fungsi pemerintahan yang oleh undang-undang tidak ditentukan sebagai yang diselenggarakan pusat.

c. Prinsip kekhususan dan keragaman Daerah (Pasal 18 A, ayat (1)). Prinsip ini mengandung makna bahwa bentuk dan isi otonomi daerah tidak harus seragam (uniformitas). Bentuk dan isi otonomi daerah ditentukan oleh berbagai keadaan khusus dan keragaman setiap daerah.

d. Prinsip mengakui dan menghormati kasatuan masyarakat hukum adat beserta hak-hak tradisionalnya (Pasal 18 B, ayat (2)). Yang dimaksud masyarakat hukum adat adalah masyarakat hukum (rechtsgemeenschap) yang berdasarkan hukum adat atau adat istiadat seperti desa, marga, nagari, gampong, meunasah, huta, negorij dan lain-lain. Kesatuan-kesatuan masyarakat hukum ini tidak hanya diakui

\footnotetext{
${ }^{7}$ Yusnani, Hukum Pemerintahan Daerah, Cetakan Ke-1, RajaGrafindo Persada, Jakarta, 2017, hlm. 17.

${ }^{8}$ Bagir Manan, Menyongsong, Op. Cit., hlm. 7-17.
} 
tetapi dihormati, artinya mempunyai hak hidup yang sederajat dan sama pentingnya dengan kesatuan pemerintahan lain seperti kabupaten dan kota.

e. Prinsip engakui dan menghormati pemerintahan daerah yang bersifat khusus dan istimewa (Pasal 18 B ayat (1)). Pasal 18 lama, menyebutkan: "hak asal-usul dalam daerahdaerah yeng bersifat istimewa". Penjelasan menyebutkan bahwa daerah-daerah yang bersifat istimewa mencakup "zelfbesturende landshappen" (swapraja), dan "volksgemeenschappen" (desa, marga, dan lain-lain). Kalau demikian, yang dimaksud "Bersifat istimewa" adalah pemerintahan asli atau pemerintah bumiputra. Tidak ada daerah khusus. Dalam Pasal 18 B, perkataan "Khusus" akan memiliki cakupan yang lebih luas, antara lain karena dimungkinkan membentuk pemerintahan daerah dengan otonomi khusus (Aceh, Irian Jaya).

f. Prinsip Badan Perwakilan dipilih langsung dalam suatu pemilihan umum (Pasal 18 ayat 3). Dengan demikian tidak ada lagi keanggotaan DPRD yang diangkat.

g. Prinsip hubungan pusat dan daerah harus dilaksanakan secara selaras dan adil (Pasal 18 A ayat (2)). Meskipun tidak ada satu ukuran tertentu mengenai hubungan yang adil dan selaras, prinsip ini menunjukkan, bahwa daerah berhak memperoleh secara wajar segala sumber daya untuk mewujudkan pemerintahan daerah yang mandiri.

Secara Kontitusional perjalanan politik hukum otonomi daerah atau pemerintahan daerah di Indonesia memang mengalami perubahan yang cukup signifikan bukan hanya terletak pada penambahan jumlah pasal atau muatan paragraf dalam UUD NRI 1945 saja. Namun, paradigma yang dituangkan dalam Pasal 18, Pasal 18A, dan Pasal 18B. Otonomi Daerah bukan hanya sekedar pelimpahan kewenangan dari pemerintah pusat kepada pemerintah di daerah, tetapi juga terkait dengan pengakuan atas hak asal-usul dari sebuah eksistensi kearifan lokal (menghargai dan menghormati kekhususan dan keistimewaan) dalam pemerintahan di daerah, hal tersebut sering dimaknai sebuah desentralisasi asimetris.

Hubungan antara otonomi daerah dengan negara kesatuan memang sering kali menimbulkan perdebatan. Namun yang harus menjadi patokan bahwa adanya otonomi dalam sebuah negara kesatuan bukan masalah tentang kebebasan dalam mengurus dan mengatur rumah tangga pemerintahan daerah semata. Otonomi harus dipandang sebagai sebuah solusi penyelenggaraan pemerintahan dengan keberagaman masyarakat. Otonomi memungkinkan terlaksananya bottum up planning secara signifikan dan mengikis rantai birokrasi yang dirasakan sangat menghambat pelayanan kepada masyarakat. Otonomi juga akan dapat 
memberdayakan partisipasi masyarakat yang lebih besar dalam pelaksanaan pembangunan. ${ }^{9}$

Berkaitan dengan penyelenggaraan pemerintahan di Indonesia, otonomi diarahkan pada beberapa hal yaitu: Pertama, dari aspek politik pemberian otonomi daerah bertujuan untuk mengikutsertakan dan menyalurkan aspirasi masyarakat ke dalam program-program pembangunan baik untuk kepentingan daerah sendiri maupun untuk mendukung kebijakan nasional tentang demokrasi. Kedua, dari aspek menejemen pemerintahan, pemberian otonomi daerah bertujuan meningkatkan daya guna penyelenggaraan pemerintahan terutama dalam memberikan pelayanan dalam berbagai kebutuhan masyarakat. Ketiga, dari aspek kemasyarakatan pemberian otonomi daerah bertujuan meningkatkan partisipasi serta menumbuhkembangkan kemandirian masyarakat untuk tidak perlu banyak bergantung kepada pemberian pemerintah dalam proses pertumbuhan daerahnya sehingga daerah memiliki daya saing yang kuat. Keempat, dari aspek ekonomi pembangunan, pemberian otonomi daerah bertujuan menyukseskan pelaksanaan program pembangunan guna tercapainya kesejahteraan rakyat yang makin meningkat. ${ }^{10}$

Secara teoretis dan faktual, pembentukan daerah otonom melalui desentralisasi tidak akan menjadi penyebab terjadinya disintegrasi nasional, tetapi justru sangat kondusif bagi tercapainya integrasi nasional. Pemberian status otonomi kepada kelompok-kelompok masyarakat di wilayah masing-masing akan mendorong warga masyarakat berpartisipasi dalam skala daerah dan nasional. Dengan demikian akan terwujud unity within diversity dan diversity in unity.11

\section{Pertanggungjawban Penyelenggaraan Pemerintahan}

Pertanggungjawaban berasal dari kata tanggung jawab, yang berarti keadaan wajib menanggung segala sesuatunya (kalau ada suatu hal, boleh dituntut, dipersalahakan, diperkarakan, dan sebagainya).12 Tanggungjawab dikaitkan dengan sesuatu keharusan yang diberengi dengan sanksi, bila terdapat sesuatu

\footnotetext{
${ }_{9}$ Djoko Sudantoko, Dilema Otonomi Daerah, Andi Offset, Yogyakarta, 2003, hlm. 5.

${ }_{10}$ Zudan Arif Fakrulloh, Hukum Indonesia dalam Berbagai Prespektif, Cetakan Pertama, Raja Grafindo Persada,

${ }^{11}$ Didik Sukriono, Hukum Konstitusi dan Konsep Otonomi, Cetakan Pertama, Setara Press, Malang, 2013, hlm. 124.

12 Ridwan HR, Hukum Administrasi Negara, Cetakan ke 9, RajaGrafindo Persada, Jakarta, 2013, hlm. 318.
} Jakarta, 2014, hlm. 22. 
yang tidak beres dalam keadaan wajib menanggung segala sesuatu tersebut. Pertanggungjawaban biasanya diartikan sebagai proses pribadi yang menyangkut tindakan, perbuatan, atau keputusan seseorang dalam hubungannya dengan orang lain sehingga ia dapat menerima hak dan wewenang tertentu berikut sanksi yang menjadi konsekuensinya. Akan tetapi dalam administrasi publik pertanggungjawaban mengandung tiga konotasi: ${ }^{13}$

1) Pertanggungjawaban sebagai Akuntabilitas (accountability) Akuntabilitas di sini berperan jika suatu lembaga (agency) harus bertanggungjawab atas kebijakan-kebijakan (policies) tertentu.

2) Pertanggungjawaban sebagai Sebab-Akibat (cause)

Jenis pertanggungjawaban ini muncul bila orang mengatakan bahwa suatu lembaga diharuskan untuk mempertanggungjawabkan jalannya suatu urusan (the conduct of some affairs).

3) Pertanggungjawaban sebagai Kewajiban (obligation)

Apabila seseorang bertanggungjawab dalam artian kewajiban untuk melakukan sesuatu, itu berarti bahwa: 1) dia harus menggunakan kapasitas untuk melakukan pertanggungjawaban kausal keapada orang yang memberinya delegasi, dalam rangka menyempurnakan hal-hal yang dipertanggungjawabkan tersebut, 2) dia harus melaksanakan setiap tahapan dari kontribusi kausalnya secara ekpslisit.

Salah satu asas negara hukum yakni setiap tindakan organ pemerintah harus berdasarkan kewenangan, terkait erat dengan asas "geen bevoegheid zonder varantwoordelijkheid" (tidak ada kewenangan tanpa pertanggungjawaban) atau "zonder bevoegdheid geen verantwoordelijkheid" (tanpa kewenangan tidak ada pertanggungjawaban). Pada umumnya setiap tindakan organ pemerintahan adalah penggunaan wewenang, karena itu selalu terkait dengan pertanggungjawaban. Titiek Sri Djatmiati mengatakan bahwa "setiap penggunaan kewenangan apapun bentuknya apakah dalam rangka pengaturan, pengawasan, maupun penentuan sanksi oleh badan pemerintah selalu disertai dengan adanya tanggung jawab. ${ }^{14}$

Menurut Lukman Hakim mengkategorikan pertanggungjawaban dalam dua macam, yaitu (1) Pertanggungjawaban moral (moral responsibility); dan (2) Pertanggungjawaban politik menurut erman finer (pertanggungjawaban sensor).

13 Herbert J. Spiro, Responsibility in Goverment Theory and Practice, New York, Van Nostrand Reinhold Company, 1969, hlm: 14, telah dikutip kembali oleh Wahyudi Kumorotomo, Etika administrasi Negara, Cetakan Ke-2, RajaGrafindo Persada, Jakarta, 1994, hlm. 146.

${ }^{14}$ Ridwan, Diskresi dan Tanggung Jawab Pemerintah, Cetakan Pertama, FH UII Press, Yogyakarta, 2014, hlm. 188. 


\section{Ifx Renaissance No. 2 VOL. 2 JULI 2017: 231 - 258}

Pertanggungjawaban moral adalah pertanggungjawaban yang tidak menuntut sanksi yuridis, karena pentaatannya tidak dipaksakan dari luar (secara heteronom), tetapi pentaatannya otonom dari dalam nurani "pejabat" atau penguasa yang berwenang itu sendiri. Meskipun dalam "pertanggungjawaban" moral (moral responsibility) tidak mengakibatkan dapat dijatuhkan sanksi yuridis, tetapi dalam mengimplementasikan hukum positif, badan atau lembaga negara tidak dibenarkan mengabaikan asas-asas moral. Di balik pertanggungjawaban moral terdapat pertanggungjawaban politik adalah pertanggungjawaban yang menimbulkan akibat dapat dijatuhkannya sanksi "politik" berupa pemecatan dari jabatan "pejabat" atau penguasa yang berwenang dari jabatannya sebelum masa jabatannya berakhir (impeachment). ${ }^{15}$

Menurut Brautigam, pertanggungjawaban pemerintah terdiri atas 3 (3) jenis yakni pertanggungjawaban politik (politcal accountability), pertanggungjawaban hukum (legal accountability) dan pertanggungjawaban ekonomi (economic accountability). Pertanggungjawbaan politik dalam realitasnya berkaitan dengan sistem politik atau lebih memusatkan pada tekanan demokrasi (democatic pressure). Menurut Syarif Muhammad Nuh Pertanggungjawaban secara politik jika ditarik dalam penyelenggaraan pemerintahan daerah dapat berupa Laporan penyelenggaraan pemerintahan daerah oleh Pemerintah Daerah Kepada Pemerintah yang kemudian dilakukan evaluasi berupa pembidaan, dan Laporan Keterangan Keterangan Pertanggungjawaban kepada DPRD. ${ }^{16}$

Selanjutnya, pertanggungjawaban hukum mengandung arti bahwa Pemerintah Daerah dalam menyelenggaraan pemerintahan yang merugikan kepentingan rakyat atau pihak lain harus mempertanggungjawabkan dan menerima tuntutan hukum atas tidakannya tersebut. Pertanggungjawaban hukum dapat dilakukan melalui pendayagunaan 3 (tiga) sarana hukum yakni sarana hukum administasi, hukum pidana dan hukum perdata. Berdasarkan instrument hukum tersebut, maka dikenal adanya tanggung jawab administrasi, tanggung jawab pidana, dan tanggung jawab perdata. ${ }^{17}$

\footnotetext{
${ }^{15}$ Lukman Hakim, Filosofi Kewenangan Organ \& Lembaga Daerah, Setara Press, Malang, 2012, hlm. 44.

16 Muhammad Syarif Nuh, "Hakikat Pertanggungjawaban Pemerintah Daerah Dalam Penyelenggaraan Pemerintahan”, Jurnal MMH, Vol. 41, 12 Januari 2012, hlm. 55.

${ }^{17}$ Ibid., hlm. 57.
} 
Sedangkan mengenai pertanggungjawaban di bidang ekonomi, menurut Nisjar, pertanggungjawaban ekonomi (keuangan) mengandung arti bahwa aparat pemerintah wajib mempertanggungjawabkan setiap rupiah uang rakyat dalam anggaran belanjanya yang bersumber dari penerimaan pajak dan retribusi. Pertanggungjawaban ekonomi mensyaratkan agar pemerintah memberikan laporan mengenai penguasaan atas dana-dana publik dan penggunaannya sesuai dengan peruntukannya. Selain itu, pemerintah harus dapat pula mempertanggungjawabkan kepada rakyat berkenaan dengan penggalian atau pemungutan sumber dana publik dan tujuan penggunaannya. ${ }^{18}$ Penyelenggaraan Pemerintahan sejatinya harus dipertanggungjawabankan kepada pemberi kekuasaan atas penyelenggaraan pemerintahan, di mana dalam sebuah negara hukum yang demokratis kekuasaan atau kewenangan penyelenggaraan pemerintahan datang dari rakyat. Pertanggungjawaban kepada rakyat menurut Bagir Manan dapat dilakukan dalam dua cara yaitu melalui wakil rakyat atau langsung kepada rakyat.19

Apabila ditarik benang merah mengenai pertanggungjawaban penyelenggaraan pemerintahan yang telah dikemukakan di atas, dapat dijelaskan bahwa pertanggunggungjawaban pemerintahan diawali dari pertanggungjawaban politik. Di mana pertanggungjawaban politik dapat berujung ke dalam pertanggungjawaban hukum maupun ekonomi. Pertanggungjawaban politik penyelenggaraan pemerintahan daerah yang diwujudkan dalam laporan penyelenggaraan pemerintahan daerah kepada pemerintah pusat, maupun Laporan Keterangan Pertanggungjawaban Kepala Daerah kepada DPRD, kedua laporan tersebut didasarkan pada perencanaan pemerintahan daerah yang dituangkan dalam Peraturan Daerah yang apabila terjadi ketidaksesuaian dalam pelaksanaannya, pasti akan berakibat hukum. Sedangkan jika dikaitkan dengan pertanggungjawaban ekonomi, segala kebijakan dan perencanaan pemerintahan daerah pasti berkaitan dengan pengelolaan keuangan daerah yang berasal dari pendapatan asli daerah maupun dana perimbangan yang segalanya itu berasal dari masyarakat yang harus dapat dipertanggungjawabkan.

\footnotetext{
18 Ibid., hlm. 58.

${ }_{19}$ Bagir Manan, Menyongsong ..., Op. Cit., hlm. 251.
} 


\section{Ifx Renaissance No. 2 VOL. 2 JULI 2017: 231 - 258}

\section{Politik Hukum Pertanggungjawaban Kinerja Kepala Daerah Pasca Reformasi \\ Politik Hukum Pertanggungjawaban Kepala Daerah dalam Undang-Undang Nomor 22 Tahun 1999}

Undang-Undang Nomor 22 Tahun 1999 tentang Pemerintahan Daerah adalah sebuah bukti awal dari demokratisasi dalam Pemerintahan Negara Kesatuan Republik Indonesia. Selain tuntutan untuk keluar dari belenggu penyelenggaraan pemerintahan masa Orde baru yang sentralis, penyelenggaraan pemerintahan daerah berdasarkan asas otonomi atau desentralisasi juga menjadi sebuah hal yang wajib diwujudkan di era reformasi. Undang-Undang No. 22 Tahun 1999 yang menggantikan UU No. 5 Tahun 1974 memberikan paradigma baru dan sebuah bentuk demokratisasi ditingkat daerah. Ketika UU No. 22 Tahun 1999 masih dalam proses pembahasan, RUU tentang Pemerintahan Daerah merupakan suatu pengaturan yang sangat strategis. Adanya RUU tentang Pemerintahan daerah saat itu merupakan sebuah perombakan total dan mendasar untuk menggantikan UU No. 5 Tahun 1974 tentang Pemerintahan Daerah dan UU No. 5 Tahun 1979 tentang Pemerintahan Desa.

Kebijakan otonomi daerah melalui UU No. 22 Tahun 1999 memberikan otonomi yang sangat luas kepada daerah, khususnya Kabupaten dan Kota. Hal itu ditempuh dalam rangka mengembalikan harkat dan martabat masyarakat di daerah, memberi peluang pendidikan politik dalam peningkatan kualitas demokrasi di daerah, peningkatan efisiensi pelayanan publik di daerah, peningkatan percepatan pembangunan daerah, dan pada akhirnya diharapkan pula penciptaan cara berpemerintahan yang baik (good governance). ${ }^{20}$ Hal tersebut di dasarkan pada pengalaman masa lalu, di mana kebijakan otonomi lebih ditekankan pada tuntutan tanggungjawab, daerah tidak diberikan peluang untuk mengambil keputusan atau kebijakasanaan yang dapat dipandang merugikan kepentingan Pusat.

Selanjutnya untuk menelaah lebih lanjut tentang kebijakan otonomi daerah yang dimaksud dalam UU No. 22 Tahun 1999, dapat dipahami dalam hasil pembahasan Pansus kala itu tentang materi pokok dari RUU Pemerintahan Daerah mengerucut pada beberapa aspek penyelenggaraan pemerintahan daerah diantaranya ${ }^{21}$ :

\footnotetext{
${ }^{20}$ Syaukani HR, Otonomi Daerah Dalam Negara Kesatuan, (Pustaka Pelajar, Yogyakarta, 2002), hlm. 211.

${ }^{21}$ Risalah Sidang RUU Pemerintahan Daerah Tahun 1999 Bagian Pendahuluan hlm. xii
} 
a. Penyelenggaraan otonomi daerah dilaksanakan dengan memperhatikan aspek demokrasi, keadilan dan pemerataan serta memperhatikan potensi dan keanekaragaman daerah. Pelaksanaan otonomi daerah didasarkan pada otonomi luas ${ }^{22}$, nyata dan bertanggungjawab. Pelaksanaan otonomi daerah yang luas dan utuh tersebut diletakkan pada daerah tingkat II yaitu Kabupaten dan Kota, sedangkan otonomi daerah Propinsi merupakan otonomi yang terbatas, disamping Propinsi tetap menyelenggarakan asas dekonsentrasi sebagai wilayah administrasi, propinsi berfungsi pula sebagai pengikat hubungan antara Pusat dan Daerah dalam rangka memelihara keutuhan Negara Kesatuan Republik Indonesia dan juga bertugas melaksanakan kewenangan pemerintahan yang bersifat lintas daerah Kabupaten dan Kota.

b. Pelaksanaan otonomi daerah yang lebih meningkatkan peranan dan fungsi Badan Legislasi Daerah, baik dalam melaksanakan fungsi legislasi, fungsi pengawasan maupun fungsi anggaran atas penyelenggaraan Pemerintahan Daerah. ${ }^{23}$ DPRD sepenuhnya memiliki kewenangan memilih dan menetapkan Kepala Daerahnya terutama pada Kabupaten dan Kota tanpa harus berkonsultasi atau meminta restu dengan pimpinan diatasnya. DPRD dapat meminta Kepala Daerah berhenti apabila pertanggungjawaban Kepala Daerah setelah 2 (dua) kali tidak dapat diterima oleh DPRD.

c. Kewenangan otonomi daerah merupakan kewenangan yang utuh dalam pengertian bahwa seluruh kewenangan pemerintahan dapat diselenggarakan oleh daerah otonom, kecuali kewenangan mutlak pemerintah pusat yang tidak diotonomikan. ${ }^{24}$

d. Fungsi Kecamatan tidak lagi sebagai wilayah administrasi atau perangkat dekonsentrasi dalam lingkungan daerah otonom Kabupaten atau Kota, namun kecamatan berkedudukan sebagai perangkat Daerah Kabupaten dan Kota.

e. Penyelenggaraan Pemerintahan Daerah merupakan sub sistem dari sistem penyelenggaraan pemerintahan sebagai perwujudan demokrasi, di desa dibentuk Badan Perwakilan Desa yang berfungsi sebagai lembaga legislasi dan pengawasan dalam hal pelaksanaan pengaturan desa, Anggaran Pendapataan dan Belanja Desa dan Keputusan Kepala Desa. ${ }^{25}$

Jika melihat dari susunan dan bentuk pemerintahan daerah yang ada di UU

No. 22 Tahun 1999 lebih mencerminkan sebuah mekanisme hubungan

\footnotetext{
${ }^{22}$ Salah satu implikasi dari penerapan prinsip otonomi daerah yang luas adalah pemberian wewenang di bidang kepegawaian. Daerah Otonomi diberi kewenangan untuk melakukan pengangkatan, pemindahan, pemberhentan, penetapan pensiungaji, tunjangan dan kesejahteraan pegawai, pendidikan dan pelatihan pegawai sesuai dengan kebutuhan dari kemampuan daerah yang ditetapkan dengan peraturan Daerah.

${ }^{23}$ Dalam organisasi Pemerintah Daerah Otonom memisahkan kedudukan DPRD dari Kepala Daerah, DPRD ditempatkan sebagai lembaga legislatif daerah, dan Kepala Daerah sebagai pimpinan eksekutif

${ }^{24}$ Kewenangan mutlak pemerintah pusat yang tidak diotonomikan yaitu bidang hubungan luar negeri, Pertahanan Keamanan, Peradilan, Moneter dan Fiskal serta kewenangan Bidang Agama, dan kewenangan strategis lainnya.

${ }^{25}$ Kepala Desa bertanggungjawab pada Badan Perwakilan Desa dan menyampaikan Laporan Pelaksanaan tugas pada Bupati.
} 


\section{Ifx Renaissance No. 2 VOL. 2 JULI 2017: 231 - 258}

kewenangan yang sejajar sebagaimana dimaksud dalam Pasal 1 huruf $d$ Pemerintahan Daerah adalah penyelenggaraan Pemerintahan Otonom oleh Pemerintah Daerah dan DPRD menurut asas Desentralisasi. ${ }^{26}$ Pada dasarnya UU No. 22 Tahun 1999 menurut Syarwan Hamid ${ }^{27}$ bukan hanya sekedar mengubah dua UU sebelumnya yaitu UU No. 5 Tahun 1974 dan UU No. 5 Tahun 1979 saja tetapi juga bermaksud menawarkan perubahan mendasar dan substansial mengenai pengertian-pengertian otonomi daerah yang sangat berbeda dengan sebelumnya. Jika di dalam UU No. 5 Tahun 1974 pelaksanaan otonomi daerah lebih mengedepankan otonomi sebagai kewajiban dari pada hak, maka di dalam UU No. 22 Tahun 1999 menekankan arti penting kewenangan Daerah dalam mengatur dan mengurus kepentingan masyarakat melalui prakarsanya sendiri.

Penyelenggaraan pemerintahan daerah akan berlangsung secara efisien dan efektif manakala sistem yang digunakan mampu menjamin adanya mekanisme yang memungkinkan pembagian kekuasaan. Oleh karena itu, di dalam UU No. 22 Tahun 1999 diatur mengenai organisasi pemerintah daerah otonom yang memisahkan kedudukan DPRD dari Kepala Daerah. DPRD ditempatkan sebagai lembaga legislatif daerah dan Kepala Daerah sebagai pimpinan eksekutif daerah. Pemisahan antara DPRD dengan Kepala Daerah dimaksudkan untuk lebih memberdayakan DPRD dan meningkatkan pertanggungjawaban pemerintah daerah kepada rakyat. Untuk itu kepada DPRD diberikan hak-hak yang cukup luas dan memungkinkan DPRD mampu menyerap serta menyalurkan aspirasi masyarakat menjadi kebijakan daerah, serta melaksanakan fungsi pengawasan secara efektif. 28

Secara konseptual UU No. 22 Tahun 1999 memberikan sebuah bentuk demokratisasi peyelenggaraan pemerintahan, di mana demokratisasi tesebut diwujudkan dalam pemilihan Kepala Daerah yang dipilih secara demokratis. Pemilihan Kepala Daerah secara demokratis dalam UU tersebut dilaksanakan oleh

\footnotetext{
${ }^{26}$ Yang dimaksud Pemerintah Daerah adalah Kepala Daerah beserta perangkat Daerah otonom yang lain sebagai Badan Eksekutif Daerah, sedangkan Dewan Perwakilan Rakyat Daerah, selanjutnya disebut DPRD, adalah Badan Legislatif Daerah.

${ }^{27}$ Menteri Dalam Negeri Republik Indonesia pada Kabinet Reformasi Pembangunan, Masa Jabatan 23 Mei 1998- 27 September 1999

${ }^{28}$ Risalah Sidang Rapat Paripurna ke-33 Tahun sidang 1998-1999, Pembicaraan Tingkat I/Keterangan Pemerintah tentang RUU tentang Pemerintahan Daerah, Rabu 10 Februari 1999
} 
DPRD yang diberikan kewenangan memilih Kepala Daerah baik Gubernur atau Bupati/Walikota. Konsekuensi dari pemilihan demokratis yang dilaksanakan oleh DPRD mengakibatkan Kepala Daerah bertanggungjawab kepada DPRD. Dalam pelaksanaan pertanggungjawaban pemerintahan daerah di tingkat Provinsi ada dua jenis yakni Kepala Daerah dalam hal ini gubernur menjalankan tugas sebagai wakil pemerintah pusat bertanggungjawab kepada Presiden. Namun selanjutnya baik Gubernur maupun Bupati/Walikota sebagai Kepala Daerah bertanggungjawab kepada DPRD (Gubernur kepada DPRD provinsi, Bupati/Walikota kepada DPRD Kabupaten/Kota).

UU No. 22 Tahun 1999 memberikan Tugas dan Wewenang DPRD berupa hak untuk meminta pertanggungjawaban Gubernur, Bupati, dan Walikota. ${ }^{29}$ Dalam pelaksanaannya Hubungan Pertanggungjawaban Kepala Daerah kepada DPRD ada beberapa macam yaitu ${ }^{30}$ :

1) Pertanggungjawaban Akhir Tahun Anggaran

Pertanggungjawaban Kepala Daerah kepada DPRD atas penyelenggaraan pemerintahan daerah selama satu tahun anggaran yang merupakan pertanggungjawaban pelaksanaan APBD berdasarkan tolok ukur Renstra.

2) Pertanggungjawaban Akhir Masa Jabatan

Pertanggungjawaban Kepala Daerah kepada DPRD atas penyelenggaraan pemerintahan daerah selama masa jabatan Kepala Daerah berdasarkan tolok ukur Renstra.

3) Pertanggungjawaban untuk hal tertentu

Pertanggungjawaban atas perbuatan pribadi Kepala Daerah dan atau Wakil Kepala Daerah yang diduga mengandung unsur tindak pidana sewaktu-waktu selama masa jabatan.

Pertanggungjawaban Kepala Daerah secara mutlak kepada DPRD merupakan konsekuensi dari proses pengisian jabatan Kepala Daerah maupun Wakil Kepala Daerah yang dilakukan dan dipilih oleh DPRD melalui mekanisme pencalonan dan pemilihan. Selanjutnya calon Kepala Daerah dan calon Wakil Kepala Daerah yang mendapatkan suara terbanyak dalam pemilihan yang

${ }^{29}$ Dalam menjalankan tugas dan kewenangan sebagai Kepala Daerah, Gubernur bertanggungjawab kepada DPRD Propinsi, dan Dalam menjalankan tugas dan kewenangan selaku Kepala Daerah, Bupati/Walikota bertanggung jawab kepada DPRD Kabupaten/Kota.

${ }^{30}$ Lihat Pasal 1 angka 6, 7, dan 8 PP No. 108 Tahun 2000 
dilakukan oleh DPRD ditetapkan sebagai Kepala Daerah dan Wakil Kepala Daerah oleh DPRD dan disahkan oleh Presiden.

Kepala Daerah memimpin penyelenggaraan Pemerintahan Daerah berdasarkan kebijakan yang ditetapkan bersama DPRD. ${ }^{31}$ Sebagai pemimpin penyelenggaraan pemerintahan daerah Kepala Daerah bertanggungjawab kepada DPRD. Sedangkan hubungan antara Kepala Daerah sebagai pemimpin penyelenggaraan Pemerintahan Daerah dengan Pemerintah Pusat dalam hal ini kepada Presiden terlihat dalam bunyi Pasal 44 ayat (3) "Kepala Daerah wajib menyampaikan laporan atas penyelenggaraan Pemerintahan Daerah Kepada Presiden melalui Menteri Dalam Negeri dengan tembusan kepada Gubernur bagi Kepala Daerah Kabupaten dan Kepala Daerah Kota, sekurang-kurangnya sekali dalam satu tahun, atau jika dipandang perlu oleh Kepala Daerah atau apabila diminta oleh Presiden".

Menurut J. Kaloh, model pertanggungjawban Kepala Daerah kepada DPRD, dimaksudkan agar penyelenggaraan pemerintahan di daerah benar-benar dipertanggungjawabkan kepada rakyat daerah melalui DPRD. Dengan demikian, Kepala Daerah akan lebih memperhatikan kepentingan rakyat daerah. ${ }^{32}$ Hubungan pertanggungjawaban Kepala Daerah dengan DPRD juga dapat berujung sebuah pemberhentian Kepala Daerah apabila pertanggungjawaban Kepala Daerah ditolak oleh DPRD. Kepala Daerah yang ditolak pertanggungjawabannya oleh DPRD, baik pertanggungjawaban kebijakan pemerintahan maupun pertanggungjawaban keuangan, harus melengkapi dan/atau menyempurnakannya dalam jangka waktu paling lama tiga puluh hari dan selanjutnya disampaikan kembali pertanggungjawaban yang sudah disempurnakan kepada DPRD. Selanjutnya apabila bagi Kepala Daerah pertanggungjawabannya ditolak untuk kedua kalinya, DPRD dapat mengusulkan pemberhentiannya kepada Presiden.

UU No. 22 Tahun 1999 sebenarnya merupakan sebuah harapan akan demokratisasi dan pemberdayaan daerah, namun ternyata banyak terjadi ketidak stabilan mengenai hubungan antara DPRD dengan Kepala Daerah. Dalam praktiknya banyak terjadi kegaduhan politik dan ketidak harmonisan hubungan antara DPRD dengan Kepala Daerah. Menurut beberapa pakar memang UU No. 22

\footnotetext{
${ }^{31}$ Lihat Pasal 44 ayat (1) UU No. 22 Tahun 1999

32 J. Kaloh, Kepemimpnan Kepala Daerah, Cetakan Pertama, Sinar Grafika Offset, Jakarta, 2009, hlm. 170-171.
} 
Tahun 1999 ketika menyelesaikan persoalan mengenai penyelenggaraan pemerintahan daerah khususnya hubungan DPRD dan Kepala Daerah lebih menekankan pada penyelesaian secara politis. DPRD juga dianggap lebih tinggi kedudukannya dibandingkan Kepala Daerah.

Periode berlakunya UU No. 22 Tahun 1999 telah memberikan dampak negatif dalam kestabilan perpolitikan ditingkat daerah, karena terjadi disharmonisasi antara DPRD dan Kepala Daerah. Posisi DPRD dianggap lebih superior dibandingkan Kepala Daerah, sebagaimana terjadi di beberapa daerah misalnya dalam kasus pemecatan 'Cak Narto atau Sunarto Sumoprawiro' (Walikota Surabaya) dengan alasan kesehatan. Selanjutnya jabatan tersebut digantikan oleh Bambang DH yang kemudian oleh DPRD LPJ Walikota Bambang DH ditolak pada 12 Juni 2002. Saat itu ada tiga fraksi di DPRD Surabaya yaitu FKB, F.Gabungan, dan F.TNI/Polri menolak LPJ Tahunan Walikota Bambang DH. Dalam kasus penolakan LPJ ini, Walikota Bambang DH memiliki argumen bahwa LPJ yang diterima DPRD Surabaya itu menjadi tanggungjawab Walikota sebelumnya sehingga Bambang DH menolak untuk merevisinya. 33

Kasus disharmonisasi antara DPRD dan Kepala Daerah juga nampak di beberapa daerah, diantaranya Kasus Pemecatan Gubernur Kalimantan Selatan 'Sjachriel Darham' pada bulan Agustus 2002. Namun yang terjadi pemecatan itu dibatalkan oleh Mendagri melalui SK Mendagri No. 121.143-110 tertanggal 26 Februari 2003. "Korban" pemecatan DPRD lainnya adalah Bupati Kampar Jefri Noer (di Riau) dan Wakilnya A. Zakir, yang diberhentikan DPRD Kabupaten Kampar pada Sidang Paripurna 12 Oktober 2002, padahal baru menjabat selama 11 bulan. ${ }^{34}$ Dalam praktik penyelenggaraan pemerintahan daerah, DPRD periode UU No. 22 Tahun 1999 terasa sangat superior terhadap Kepala Daerah, padahal harapan dari UU tersebut ialah untuk menjaga terlaksananya demokrasi dan kesejajaran yang bersifat kemitraan antara kedua lembaga daerah tersebut.

33 Tri Ratnawati, Problematik Implementasi UU No. 22 Tahun 1999, dalam Membangun Format Baru Otonomi Daerah, LIPI Press, Jakarta, 2006, hlm. 137.

34 Ibid., hlm. 138 
Politik Hukum Pertanggungjawaban Kepala Daerah dalam Undang-Undang Nomor 32 Tahun 2004

Salah satu alasan mengapa UU No. 22 Tahun 1999 diubah ialah karena UU tersebut masih memberikan kesan negatif dalam penyelenggaraan pemerintahan daerah. Dampak negatif tersebut diantaranya adalah munculnya arogansi beberapa daerah, sehingga terkesan terjadi "pembangkangan" di beberapa daerah. Selain pembangkangan, hal lain yang tampak adalah dominasi DPRD atas Kepala Daerah yang mempunyai kewenangan memberhentikan Kepala Daerah dengan alasan pertanggungjawaban tahunannya tidak diterima oleh DPRD, sehingga mengakibatkan hubungan antara Kepala Daerah dengan DPRD di beberapa daerah menjadi tidak harmonis. ${ }^{35}$ Dengan pemberlakuan UU No. 22 Tahun 1999 terkesan Kepala Daerah menjadi sub ordinat DPRD, karena Kepala Daerah dipilih dan diangkat oleh DPRD kemudian mempertanggungjawabkan kepada DPRD pula.

Penyelenggaraan pemerintahan daerah berjalan dengan dominasi legislatif atas esekutif (legislative heavy). Hal ini menimbulkan kesan bahwa DPRD berada di atas Kepala Daerah, yang seringkali tidak berdaya menghadapi sepak terjang DPRD. Kasus pemberhentian Kepala Daerah (Gubernur atau Bupati/Walikota) oleh DPRD seringkali terjadi pada periode berlakunya UU No. 22 Tahun 1999. Salah satu contoh konkrit dan populer adalah kasus pemberhentian Walikota Surabaya yang dilakukan selama 2 Kali pada satu masa jabatan, yakni Walikota Soenarto Soemprawiro yang diberhentikan oleh DPRD karena alasan sakit, yang kemudian berhasil diberhentikan. Kemudian penggantinya, Bambang Dwi Hartono juga diberhentikan oleh DPRD dengan alasan pertanggungjawaban tahunannya tidak diterima meski telah diberi kesempatan untuk memperbaiki namun tetap tidak diterima. ${ }^{36}$

UU No. 32 Tahun 2004 secara politis memang menekankan adanya kesejajaran antara DPRD dengan Kepala Daerah, di mana belajar dari pengalaman yang pernah terjadi ketika berlakunya UU No. 22 Tahun 1999, Kepala Daerah begitu tersandra oleh manufer DPRD yang ketika itu dipandang sangat politis dan

35 Sudono Syueb, Dinamika Hukum Pemerintahan Daerah Sejak Kemerdekaan sampai Era Reformasi, Cetakan Pertama, Laksbang Mediatama, Surabaya, 2008, hlm. 81.

36 Ibid., hlm. 82. 
mudah saja menjatuhkan Kepala Daerah. Berangkat dari latar belakang itu ada tuntutan untuk melaksanakan Pemilihan Kepala Daerah secara langsung. Mengenai pemilihan Kepala Daerah memang tidak secara tegas dijelaskan dalam UUD NRI 1945, pemilihan itu dilakukan secara langsung oleh rakyat atau dilakukan oleh DPRD secara demokratis, karena memang dalam UUD NRI 1945 hanya menjelaskan dalam Pasal 18 ayat (4) "Gubernur, Bupati, dan Walikota masing-masing sebagai Kepala Daerah provinsi, kabupaten, dan kota dipilih secara demokratis".

Lahirnya UU No. 32 Tahun 2004 tantang Pemerintahan daerah menggantikan UU No. 22 Tahun 1999, yang sebagian besar isinya mengatur pemilihan Kepala Daerah secara langsung oleh rakyat, di mana secara konseptual menempatkan Kepala Daerah dan DPRD dalam posisi yang seimbang dan saling mengontrol, sebagaimana dikemukakan oleh Sutoro Eko bahwa "Undang-Undang No. 32 Tahun 2004 mencoba mengembalikan hubungan kerja eksekutif dan legislatif yang setara dan bersifat kemitraan. DPRD dan Kepala Daerah sama-sama dipilih oleh rakyat. Sebagai eksekutif Kepala Daerah melaksanakan aturan, dan DPRD sebagai legislatif membuat aturan. Kepala Daerah melaksanakan program, sedangkan DPRD melakukan pengawasan, mereka bersama-sama membuat budget, sehingga esensinya hak budget itu ada. ${ }^{37}$

Kesetaraan antara DPRD dan Kepala Daerah yang diwujudkan dengan samasama dipilih secara langsung oleh rakyat. Hal tersebut menjadikan kedua lembaga di daerah ini tidak memiliki hubungan pertanggungjawaban secara mutlak. DPRD sebagai lembaga perwakilan sekaligus menjadi wahana demokrasi di daerah tidak lagi bisa meminta pertanggungjawaban atas penyelenggaraan pemerintahan daerah kepada Kepala Daerah. Mekanisme berbeda mengenai pertanggungjawaban Kepala Daerah pasca perubahan UU No. 22 Tahun 1999, sudah terlihat dalam UU No. 22 Tahun 2003 tentang Susunan dan Kedudukan MPR, DPR, DPD, dan DPRD. Dalam UU tersebut, mengatur tentang tugas dan wewenang DPRD ditingkat Provinsi

${ }^{37}$ Sutoro Eko, Pembaharuan Otonomi Daerah, Cetakan Pertama, Program Studi Ilmu Pemerintahan STPMD “AMPD” dan AMPD Press, Yogyakarta, 2005, hlm. 6. 
maupun Kabupaten/Kota dijelaskan bahwa salah satunya adalah meminta lapran keterangan pertanggungjawaban gubernur dalam pelaksanaan desentraslisasi. ${ }^{38}$

Tugas dan wewenang DPRD di tingkat Provinsi maupun Kabupaten/Kota salah satunya adalah meminta laporan keterangan pertanggungjawaban gubernur, bupati, dan walikota dalam pelaksanaan desentralisasi mengakibatkan DPRD tidak lagi berwenang meminta LPJ kepada Kepala Daerah dan tidak bisa memberhentikan Kepala Daerah. ${ }^{39}$ Perubahan Tugas dan wewenang DPRD yang semula dapat meminta LPJ dengan konsekuensi pemberhentian Kepala Daerah jika LPJ ditolak, kemudian menjadi meminta LKPJ dan tidak lagi dapat memberhentikan Kapala Daerah, merupakan bentuk evaluasi dari beberapa kasus empiris yang terjadi antara DPRD dengan Kepala Daerah yang tidak harmonis.

Pengaturan lebih lanjut mengenai Laporan Keterangan Pertanggungjawaban Kepala Daerah kepada DPRD, di mana dijelaskan sebelumnya merupakan tugas dan wewenang DPRD untuk memintanya. Sebagai wujud pertanggungjawaban pemerintah daerah atas penyelenggaraan pemerintahan daerah dan pelayanan kepada masyarakat yang didasarkan pada prinsip transparansi dan akuntabilitas tersebut, maka secara periodik, Kepala Daerah dibebani kewajiban untuk menyampaikan laporan atas penyelenggaraan pemerintahan daerah kepada pemerintah pusat dan DPRD, serta menginformasikan laporan penyelenggaraan pemerintaha daerah tersebut kepada masyarakat, sebagaimana dijelaskan dalam ketentuan Pasal 27 ayat (2) UU No. 32 Tahun 2004 sebagai berikut:

Selain mempunyai kewajiban sebagaimana dimaksud pada ayat (1) Kepala Daerah mempunyai kewajiban juga untuk memberikan laporan penyelenggaraan pemerintahan daerah kepada Pemerintah, dan memberikan laporan keterangan pertanggungjawaban kepada DPRD serta menginformasikan laporan penyelenggaraan pemerintahan daerah kepada masyarakat.

Menelaah bunyi pasal di atas, maka sejak berlakunya UU No. 32 Tahun 2004 pertanggungjawaban Kepala Daerah dilakukan dengan (1) Laporan Penyelenggaraan Pemerintahan Daerah kepada Pemerintah (2) memberikan laporan keterangan pertanggungjawaban kepada DPRD serta (3)

${ }^{38}$ Lihat Pasal 62 ayat (1) huruf f dan Pasal 78 ayat (1) huruf f Undang-Undang Nomor 22 Tahun 2003.

${ }^{39}$ Keterangan dalam Daftar Inventaris Masalah (DIM) RUU Tentang Susunan dan Kedudukan MPR, DPR, DPD, dan DPRD. 
menginformasikan laporan penyelenggaraan pemerintahan daerah kepada masyarakat. Terkait LKPJ sebagaimana dijelaskan dalam Pasal 27 UU No. 32 Tahun 2004 merupakan kewajiban yang dibebankan kepada Kepala Daerah. Selanjutnya dijelaskan bahwa Laporan Keterangan Pertanggungjawaban Kepala Daerah yang menjadi tugas dan wewenang DPRD untuk memintanya. Dalam ketentuan LKPJ ini adalah laporan yang disampaikan oleh Kepala Daerah setiap tahun dalam sidang paripurna DPRD yang berkaitan dengan penyelenggaran tugas otonomi dan tugas pembantuan..$^{40}$ Ketentuan mengenai LKPJ sejak disahkannya UU No. 32 Tahun 2004 belum memberikan kejelasan pelaksanaan teknis, hanya ketika sudah diberlakukan UU No. 22 Tahun 2003 LKPJ sudah bukan menjadi alat DPRD untuk memberhentikan Kepala Daerah dengan alasan LPJ tidak diterima sebagai mana dijelaskan sebelumnya.

Ketentuan lebih lanjut mengenai Laporan Pertanggungjawaban Kepala Daerah baru dikeluarkan selang 3 tahun setelah berlakunya UU No. 32 Tahun 2004. Peraturan Pemerintah itu adalah PP No. 3 Tahun 2007 tentang Laporan Penyelenggaraan Pemerintahan Daerah Kepada Pemerintah, Laporan Keterangan Pertanggungjawaban Kepala Daerah Kepada Dewan Perwakilan Rakyat Daerah, dan Informasi Laporan Pneyelenggaraan Pemerintahan Daerah Kepada Masyarakat. Peraturan Pemerintah tersebut menjadi pedoman dalam pelaksanaan pelaporan pertanggungjawaban Kepala Daerah atas kinerjanya sampai saat ini. Mekanisme tentang pertanggungjawaban kepala daerah tidak berhenti di peraturan pemerintah itu saja melainkan juga dipertegas dalam UU No. 23 Tahun 2014 sebagai pengganti UU No. 32 Tahun 2004.

\section{Politik Hukum Pertanggungjawaban Kepala Daerah dalam Undang-Undang Nomor 23 Tahun 2014}

Politik Hukum yang terjadi dalam perubahan UU No. 32 Tahun 2004 ke UU No. 23 Tahun 2014 adalah adanya pengaturan yang mengindikasikan kuatnya kekuasaan pemerintah pusat terhadap daerah. Pasal 69 dan Pasal 71 pada intinya merumuskan bahwa setiap tahun sekali, Kepala Daerah wajib menyampaikan

\footnotetext{
${ }^{40}$ Lihat Penjelasan Pasal 42 ayat (1) Huruf h UU No. 32 Tahun 2004.
} 
laporan penyelenggaraan pemerintahan daerah kepada pemerintah "atasan" sebagai bahan evaluasi dan pembinaan dan laporan keterangan pertanggungjawaban kepada DPRD untuk rekomendasi perbaikan penyelenggaraan pemerintahan daerah. Menurut ketentuan Pasal 68, Kepala Daerah yang tidak melaksanakan program strategis nasional dapat dikenai sanksi administratif, pemberhentian sementara, dan bahkan sampai pada pemerhetian permanen.

Laporan keterangan pertanggungjawaban tidak berimplikasi pada pemberhentian Kepala Daerah. Meski demikian, Kepala Daerah (dan/atau wakilnya) yang sedang aktif menjabat dapat diberhentikan oleh DPRD, namun pemberhentiannya tidak dapat dilakukan secara sewenang-wenang oleh DPRD melalui voting. Sesuai Pasal 80, seorang Kepala Daerah dan/atau wakilnya yang akan diberhentikan karena melaggar sumpah/janji, melanggar larangan baginya, atau melakukan perbuatan tercela, harus diproses secara hukum lebih dahulu yaitu melalui persidangan di mahkamah agung untuk membuktikan kesalahannya. Jika diputuskan terbukti bersalah, baru DPRD mengusulkan pemberhentiannya kepada Presiden.

Ketika proses pembahasan masih dalam RUU telah disampaikan mengenai LKPJ. Menurut Gamawan Fauzi (Mendagri), Konsep Laporan Pertanggungjawaban (LPJ) kepada DPRD menjadi Konsep Laporan Keterangan Pertanggung Jawaban (LKPJ) kepada DPRD. LKPJ bukan sebagai instrumen untuk melakukan impeachment, tetapi lebih berfungsi sebagai "progress report" Kepala Daerah kepada DPRD dalam menyelenggarakan pemerintahan daerah. LKPJ tersebut merupakan laporan Kepala Daerah kepada DPRD sebagai mitra kerjanya mengenai pelaksanaan kebijakan yang telah disepakati oleh Kepala Daerah dengan DPRD dalam setahun melalui laporan diharapkan adanya rekomendasi dari DPRD untuk perbaikan kinerja pemerintah daerah di tahun mendatang, sedangkan proses impeachment tetap dapat dilakukan DPRD melalui instrumen interpelasi dan angket yang kemudian bermuara pada pernyataan pendapat. Mekanisme LKPJ tersbeut telah mengurangi secara signifikan gejolak yang terjadi di daerah khususnya akibat ketegangan hubungan antara Kepala Daerah dengan DPRD.41

${ }^{41}$ Risalah Proses Pembahasan RUU Tentang PEMDA 2014 dalam Rapat Kerja I Senin 2 April 2012. 
Menurut Nanang Samodra Anggota Fraksi PD pada saat itu, kedudukan DPRD ini kalau kita lihat sejarahnya setelah reformasi, bahwa dengan UU No. 22 Tahun 1999 dulu, begitu kuatnya peran DPRD sehingga pemerintah daerahnya kawalahan. Pemrintah Daerah saat itu hampir setiap saat itu selalu diteror dengan impeachment-impeachtment yang ditiupkan, diisukan oleh DPRD. Sehingga tidak tenang dalam memimpin, karena takut di Impeach. Kemudian dengan revisi UU No. 32 Tahun 2004 ini, berbalik 180 . Pemerintah Daerah tidak lagi menyampaikan laporan pertanggungjawaban, tetapi cukup Laporan Keterangan Pertanggungjawaban. Perubahan dari LPJ ke LKPJ menurutnya terlalu berat kepada Pemerintah Daerah. DPRD dirasa tidak mempunyai peran. Sehingga perlu diberikan sebuah solusi agar antara DPRD maupun Kepala Daerah dalam penyelenggaraan Pemerintahan daerah tidak berat sebelah. Bukan untuk kembali kemekanimse LPJ karena sistem yang kita anut adalah sistem kabinet presidential. Sehingga diharapkan RUU perubahan atas UU No. 32 Tahun 2004 yang seolah kewenangan DPRD ini habis. Padahal check and balances itu tetap ada antara DPRD dan Kepala Daerah. ${ }^{42}$

Ketika disahkan dan ditetapkan menjadi UU No. 23 Tahun 2014 mengenai Laporan Pertanggungjawaban Kepala Daerah juga muncul dalam Pasal 207. Esensi LKPJ dalam UU 23 Tahun 2014 ditempatkan pada mekanisme hubungan kerja kemitraan sejajar antara DPRD dengan Kepala Daerah yang selanjutnya ditegaskan penyampaian LKPJ bukan menjadi alasan atau alat pemberhentian Kepala Daerah. ${ }^{43}$ Jika ditelaah lebih lanjut LKPJ yang ada pada UU No. 32 Tahun 2004 dengan UU No. 23 Tahun 2014 tidak ada perbedaan yang signifikan, hanya saja dalam UU No. 23 Tahun 2014 dipertegas bahwa LKPJ tidak bisa dijadikan alat pemberhentian Kepala Daerah oleh DPRD.

\section{Model Ideal Pertanggungjawaban Kepala Daerah Kepada DPRD}

Hubungan pertanggungjawaban kepala daerah kepada DPRD melalui mekanisme LKPJ sebagaimana dijelaskan di atas memberikan peran yang sangat 6 Juni 2012.

42 Risalah Proses Pembahasan RUU Tentang PEMDA 2014 dalam Rapat Dengar Pendapat Umum Rabu

43 Pasal 207 UU Nomor 23 Tahun 2014. 
minim kepada DPRD untuk menjalankan fungsi pengawasan. DPRD hanya dapat memberikan rekomendasi atau saran atas LKPJ Kepala Daerah dengan tidak ada tindakan lebih janjut seperti memberikan sanksi yang mengikat apabila terjadi ketidaksesuaian antara RKPD dengan LKPJ. Untuk menciptakan sebuah check and balance antara DPRD dengan Kepala Daerah, dalam penelitian ini telah menawarkan model hubungan pertanggungjawaban Kepala Daerah dengan DPRD. Model yang ditawarkan adalah penyampaian Laporan Pertanggungjawaban Penyelenggaraan Pemerintahan dari kepala daerah kepada DPRD. Pelaksanaan LPPPD kepada DPRD merupakan bentuk pertanggungjawaban internal Pemerintahan Daerah yang selanjutnya DPRD berkewajiban membahas dan memberikan penilaian berupa Keputusan DPRD. Mekanisme LPPPD yang ditawarkan ini tidak sekaligus memutus pertanggungjawaban kepala daerah kepada pemerintah pusat. Mekanisme LPPPD kepada DPRD ini kemudian diteruskan kepada pemerintah pusat disertai dengan Keputusan DPRD yang di dalamnya berisikan penilaian atas LPPPD. Sehingga secara garis besar pertanggungjawaban Kepala Daerah disampaikan terlebih dahulu ke DPRD yang kemudian disampaikan kepada pemerintah pusat untuk dapat memberikan evaluasi terhadap kinerja kepala daerah.

Selain menerima LPPPD dari Kepala Daerah, DPRD memiliki kewajiban menyampaikan ringkasan LPPPD beserta keputusan DPRD kepada masyarakat. Hal tersebut untuk memberikan mekanisme pertanggungjawaban secara nyata kepada masyarakat, di mana kita ketahui bahwa saat ini Kepala Daerah maupun DPRD dipilih secara langsung oleh Masyarakat. Kewajiban yang dibebankan kepada DPRD untuk menyampaikan ringkasan LPPPD ini sebagai bentuk hubungan lembaga perwakilan rakyat daerah dengan masyarakat atau konstituen. Kepala Daerah juga memiliki kewajiban menyampaikan laporan realisasi penggunaan APBD sebagai bentuk pertanggungjawaban keuangan daerah kepada DPRD. Penyampaian Laporan realisasi penggunaan APBD disampaikan kepada DPRD dalam bentuk Raperda Pertanggungjawaban APBD. Hal berbeda terhadap Raperda Pertanggungjawaban APBD ini adalah DPRD dapat menolak Raperda tersebut sebagaimana dijelaskan dalam bab sebelumnya. Hubungan pertanggungjawaban yang ditawarkan dalam penelitian ini bukan semata mata 
untuk memberikan kewenangan lebih kepada DPRD, namun untuk menjaga mekanisme check and balance antara Kepala Daerah dan DPRD, serta kesetaraan yang nyata antara DPRD dengan Kepala Daerah. Selanjutnya hubungan pertanggungjawaban yang ditawarkan ini tujuan akhirnya adalah untuk menciptakan hubungan pertanggungjawaban penyelenggaraan pemerintahan daerah secara nyata kepada masyarakat.

\section{Penutup}

Politik hukum pertanggungjawaban Kepala Daerah dalam UU No. 22 Tahun 1999 menempatkan pertanggungjawban Kepala Daerah mutlak kepada DPRD. Hal tersebut dilatar belakangi dari tujuan pelaksanaan otonomi daerah yang lebih meningkatkan peran dan fungsi badan legislasi daerah, baik dalam melaksanakan fungsi legislasi, fungsi pengawasan maupun fungsi anggaran atas penyelenggaraan pewmerintahan daerah. DPRD sepenuhnya memiliki kewenangan memilih dan menetapkan Kepala Daerah terutama pada kabupaten dan kota tanpa harus berkonsultasi atau memeinta restu dengan pimpinan diatasnya. DPRD dapat meminta Kepala Daerah berhenti apabila pertanggungjawaban Kepala Daerah setelah 2 kali tidak dapat diterima oleh DPRD. Sedangkan politik hukum pertanggungjawaban Kepala Daerah dalam UU No. 32 Tahun 2004 maupun UU No. 23 Tahun 2014 lebih menegaskan konsep pertanggungjawaban Kepala Daerah melalui Laporan Penyelenggaraan Pemerintahan Daerah (LPPD) kepada Pemerintah Pusat, Laporan Keterangan Pertanggungjawaban Kepala Derah (LKPJ) kepada DPRD, dan Ringkasan Laporan Penyelenggaraan Pemerintahan Daerah kepada masyarakat secara langsung. Di mana dari ketika laporan pertanggungajwaban yang tersebut terkait evaluasi sangat didominasi Pemerintah Pusat yang dapat melakukan pembinaan, sedangkan LKPJ kepada DPRD bentuk evaluasinya hanya rekomendasi dan catatan yang bersifat saran.

Hubungan pertanggungjawaban kepala daerah kepada DPRD melalui mekanisme LKPJ sebagaimana dijelaskan di atas memberikan peran yang sangat minim kepada DPRD untuk menjalankan fungsi pengawasan. DPRD hanya dapat 
memberikan rekomendasi atau saran atas LKPJ Kepala Daerah dengan tidak ada tindakan lebih janjut seperti memberikan sanksi yang mengikat apabila terjadi ketidaksesuaian antara RKPD dengan LKPJ. Untuk menciptakan sebuah check and balance antara DPRD dengan Kepala Daerah, dalam penelitian ini telah menawarkan model hubungan pertanggungjawaban Kepala Daerah dengan DPRD. Model yang ditawarkan adalah penyampaian Laporan Pertanggungjawaban Penyelenggaraan Pemerintahan dari kepala daerah kepada DPRD. Pelaksanaan LPPPD kepada DPRD merupakan bentuk pertanggungjawaban internal Pemerintahan Daerah yang selanjutnya DPRD berkewajiban membahas dan memberikan penilaian berupa Keputusan DPRD. Mekanisme LPPPD yang ditawarkan ini tidak sekaligus memutus pertanggungjawaban kepala daerah kepada pemerintah pusat. Mekanisme LPPPD kepada DPRD ini kemudian diteruskan kepada pemerintah pusat disertai dengan Keputusan DPRD yang di dalamnya berisikan penilaian atas LPPPD. Sehingga secara garis besar pertanggungjawaban Kepala Daerah disampaikan terlebih dahulu ke DPRD yang kemudian disampaikan kepada pemerintah pusat untuk dapat memberikan evaluasi terhadap kinerja kepala daerah.

Untuk menciptakan sebuah check and balance antara DPRD dengan Kepala Daerah, dalam penelitian ini telah menawarkan model hubungan pertanggungjawaban Kepala Daerah dengan DPRD. Model yang ditawarkan adalah penyampaian Laporan Pertanggungjawaban Penyelenggaraan Pemerintahan dari Kepala Daerah kepada DPRD. Pelaksanaan LPPPD kepada DPRD merupakan bentuk pertanggungjawaban internal Pemerintahan Daerah yang selanjutnya DPRD berkewajiban membahas dan memberikan penilaian berupa Keputusan DPRD. Mekanisme LPPPD yang ditawarkan ini tidak sekaligus memutus pertanggungjawaban kepala daerah kepada pemerintah pusat. Mekanisme LPPPD kepada DPRD ini kemudian diteruskan kepada pemerintah pusat disertai dengan Keputusan DPRD yang didalamnya berisikan penilaian atas LPPPD. Sehingga secara garis besar pertanggungjawaban Kepala Daerah disampaikan terlebih dahulu ke DPRD yang kemudian disampaikan kepada pemerintah pusat untuk dapat memberikan evaluasi terhadap kinerja kepala daerah. Selain itu perlu diperhatikan untuk menempatkan DPRD diluar unsur 
penyelenggara pemerintahan daerah yang berbeda dengan Kepala Daerah. Hal tersebut akan lebih memberikan keleluasaan DPRD untuk menjalankan fungsi pengawasan sebagai badan legislatif daerah.

\section{Daftar Pustaka}

\section{Buku}

Bagir Manan, Menyongsong Fajar Otonomi Daerah, Cetakan kedua, PSH FH UII, Yogyakarta, 2002.

Didik Sukriono, Hukum Konstitusi dan Konsep Otonomi, Cetakan Pertama, Setara Press, Malang, 2013.

Djoko Sudantoko, Dilema Otonomi Daerah, Andi Offset, Yogyakarta, 2003.

J. Kaloh, Kepemimpnan Kepala Daerah, Cetakan Pertama, Sinar Grafika Offset, Jakarta, 2009.

Lukman Hakim, Filosofi Kewenangan Organ \& Lembaga Daerah, Setara Press, Malang, 2012.

Ridwan HR, Hukum Administrasi Negara, Cetakan ke 9, RajaGrafindo Persada, Jakarta, 2013.

, Diskresi dan Tanggung Jawab Pemerintah, Cetakan Pertama, FH UII Press, Yogyakarta, 2014.

Sudono Syueb, Dinamika Hukum Pemerintahan Daerah Sejak Kemerdekaan sampai Era Reformasi, Cetakan Pertama, Laksbang Mediatama, Surabaya, 2008.

Sutoro Eko, Pembaharuan Otonomi Daerah, Cetakan Pertama, Program Studi Ilmu Pemerintahan STPMD “AMPD” dan AMPD Press, Yogyakarta, 2005.

Syaukani HR, Otonomi Daerah Dalam Negara Kesatuan, Pustaka Pelajar, Yogyakarta, 2002.

Tri Ratnawati, Problematik Implementasi UU No. 22 Tahun 1999, dalam Membangun Format Baru Otonomi Daerah, LIPI Press, Jakarta, 2006.

Wahyudi Kumorotomo, Etika administrasi Negara, Cetakan Ke-2, RajaGrafindo Persada, Jakarta, 1994.

Yusnani Hasyimzoem, Hukum Pemerintahan Daerah, Cetakan Ke-1. RajaGrafindo Persada, Jakarta, 2017.

Zudan Arif Fakrulloh, Hukum Indonesia dalam Berbagai Prespektif, Cetakan Pertama, Raja Grafindo Persada, Jakarta, 2014.

\section{Jurnal}

Muhammad Syarif Nuh, "Hakikat Pertanggungjawaban Pemerintah Daerah Dalam Penyelenggaraan Pemerintahan", Jurnal MMH, Vol. 41, 12 Januari 2012. 


\section{Risalah Persidangan}

Risalah Proses Pembahasan RUU tentang PEMDA 2014 dalam Rapat Dengar Pendapat Umum Rabu 6 Juni 2012.

Risalah Proses Pembahasan RUU Tentang PEMDA 2014 dalam Rapat Kerja I Senin 2 April 2012.

Risalah Sidang Rapat Paripurna ke-33 Tahun sidang 1998-1999, Pembicaraan Tingkat I/Keterangan Pemerintah tentang RUU tentang Pemerintahan Daerah, Rabu 10 Februari 1999.

Risalah Sidang RUU Pemerintahan Daerah Tahun 1999. 